The Eurasia Proceedings of Educational \& Social Sciences (EPESS), 2014

Volume 1, Pages 489-496

ICEMST 2014: International Conference on Education in Mathematics, Science \& Technology

\title{
SERVICE LEARNING IN SCIENCE TEACHER PREPARATION PROGRAM: CONCEPTS AND PRACTICES
}

\author{
Prasart NUANGCHALERM \\ Faculty of Education, Mahasarakham University
}

\begin{abstract}
Service learning is now challenging higher education in the $21^{\text {st }}$ century. The concepts of service learning influenced to science teachers preparation program in terms of outcome-based education. The purpose of this paper aims to represent concepts relevant to service learning in science teacher preparation program and also practices of how service learning meet the $21^{\text {st }}$ century skills. Documentary analysis and empirical study are employed for qualitative explanation. Finding revealed that service learning is an important instructional strategy in science teacher preparation program and it needs to be incorporated into curriculum for developing $21^{\text {st }}$ century science teachers.
\end{abstract}

Keywords: Service learning, preservice teacher, science teacher, teacher preparation

\section{INTRODUCTION}

Learning process in the $21^{\text {st }}$ century is not appeared only in classroom-based activities, but also community service should be introduced in various kind of learning management to higher education level. That is, previous research (Zlotkowski, 2000; Gallego, 2001; Kaye, 2004; Butin, 2005; Butin, 2010; Coffey, 2011; Daniels et.al., 2011; Cone, 2012) help us to understand how to manage learning environment that meet requirement between curriculum and nature of learning. This era, we cannot deny learning management innovation propagating academic and community hit to the goal of higher education. Coffey (2011) states that the number of higher education institutions using ways to serve students' learning with service-learning programs, it is greatly increased within the last twenty years, especially teacher education programs are using them to help teacher candidates achieve an awareness of social and community issues. That is, higher education should be take responsibilities to social relations. Due to students come from community and serve community as well. They have to do with a civic mission that addresses important issue. Service learning is a significant instructional strategy which university should incorporate into course and learning activities.

Community experiences can make preservice teachers with positive attitudes, academic, skills, and attributes that classroom maybe give them less opportunity to fulfill of what they should be prospered because of school hour is limited. That why university reason lectured-based learning is restricted by content matter and space of learning. Based on framework of higher education concerns with many sectors, learning process should be widely participated in terms of community development, students are centered-based, community-based, and practicalbased needed to shape society. It is expected academic aspect and reflection which encourage our citizen autonomy and control, help them realize the link between their effort and success promote development of environmental awareness. Service learning is an educational methodology that combines community service with explicit academic learning objectives, preparation for community work, and deliberate reflection (Benneworth \& Charles, 2013). It engages students within the local community through completion of a handson construction project which response to civic engagement (Benneworth \& Humphrey, 2013; Clevenger \& Ozbek, 2013; Hart \& Aumann, 2013).

Service learning brings students and teachers to the open learning area. They have learning skills from real life situations and problem-solving. Meanwhile, service learning have itself responsible to shape way of learning by cooperative inquiry-based practices, students will have problem-solving skills and decision making through project work and serve learning outcomes through empirical evidences by community services. We can recognize instructional practices in the university level should not only emphasize on theory, most of study indicated that theoretical knowledge cannot be helped preservice teachers to fulfill learning skills. The educational practices in higher education should be focused on how learning reaches the model of learning and

- This is an Open Access article distributed under the terms of the Creative Commons Attribution-Noncommercial 4.0 Unported License, permitting all non-commercial use, distribution, and reproduction in any medium, provided the original work is properly cited.

- Selection and peer-review under responsibility of the Organizing Committee of the conference

*Corresponding author: Prasart NUANGCHALERMe-mail: prasart.n@msu.ac.th 
its assessment (Astin \& Antonio, 2012). Thus, the assessment should response to societal impact, relevant to higher education produced knowledge and human resources to society.

The notion of service learning is not new for education, is referred by experiential learning theory (Kolb \& Kolb, 2005), it is influential regarding as it provides a model of the learning process as well as model of adults' learning development. Preservice science teachers should have appropriate learning environment that institution support by various kind of theoretical-based and practical-based management. Service learning shows us socially responsible and responsive instructional practices. It also influences to authentic learning outcomes, critical reflection, and civic engagement (Galvan \& Parker, 2011). Moreover, it is an approach to teaching in which links community-based service academic and critical reflection, leads them meet the goal of experiential learning theory. This approach helps higher education curriculum build preservice teachers to have assumption a leadership role in addressing widespread of social and environmental problems, and to prepare them to be a good citizenship making them to meet the needs of a rapidly social changes (Boyer, 1990). Service learning connects authentic, meaningful service to community as well as they supported, especially to community with academic and reflection in which they have learned through scientific thinking, systemic plans, and cooperating practices (Eyler \& Giles, 1999).

Service learning enhances preservice teachers' abilities in many ways by allowing them to have learning opportunities, link academic and theories to work with real life situation, various kinds of pedagogical practices, $21^{\text {st }}$ century learning skills, social awareness, and public mind to community. As it great for learning activities in higher education, service learning incubates them not only general courses, but also preservice teachers who is lead and shape our society. According to Cone (2009a; 2009b; 2009c) studied the effect of service learning in the role of approach to enhance self-efficacy beliefs of preservice elementary teachers. The findings indicated that service learning is significantly influenced to preservice teachers with outcome expectancy towards equitable teaching and learning. It will stimulate them to have self-efficacy, has been linked to educational outcomes (Bandura, 1997). It is directly associated with behavioral, cognitive, and motivational engagement of them on academic practices (Bandura, 1993). If they have all of above and perceived that it is importance to have higher levels of cognitive engagement and also some related to their attributes (Eccles \& Wigfield, 2000). To developing preservice teachers, service learning in science teacher preparation program should fulfill cultural, social and academic awareness as well as curriculum determined.

Service-learning in teacher education programs is now growing trend in universities level which is around the world. Preservice science teachers are particularly prospered leader and transformer of social direction. The program should be challenged $21^{\text {st }}$ century skills that learning realization is overcoming in the complex society. We can say that it is an important guideline to think, imagine, plan, do, and assess for preparing quality citizen in a changing world. This study aims to present concepts and practices of service learning in science teacher preparation program. The results will be discussed and guided to curriculum development and instructional practices for science teacher preparation program.

\section{METHODOLOGY}

This study employed documentary analyses in service learning for science teacher preparation program. Document analyses are investigated through standard databases in both Thai and international sources. Thai databases can be accessed through ThaiLis, ONEC, Google Scholar, and universities' WebOPAC. International database are linked to ERIC, EBSCOHOST, Proquest, Google Scholar, Scopus, and ISI Web of Science. Information is gathered by keywords, methods, and contents related to service learning in higher education, and it is screened only related preservice science teachers and service learning documents. Concepts are drawn, reviewed, and analyzed by content analysis methods. Data are described in terms of qualitative presentation, descriptive report, and gap analysis.

The practices are reviewed research in service learning, especially for science teacher preparation program. Also, data from practices and experiences are collected through observation, participatory action, and reflection. The service learning by practical data is observed through science teacher service camp, which it have been run for 10 years in Bachelor degree of General Science program, Mahasarakham university. It can conclude to be instructional strategies. Then, researcher analyzed data and explained empirical evidences by descriptive explanation.

\section{RESULTS}

Social responsibilities are now calling for $21^{\text {st }}$ century because we have too much knowledge and technology in which concerns unlimited cognitive growing, but necessary skills and attributes need to be done with high 
quality education, high quality citizens facing complex modern life and innovation for surviving. The process of learning in school or university should not be concentrated only subject matters because the world is change, problem is more complex, natural resources and environment are ruined. Society call for all sectors to have responsibilities and awareness to do with friendly action that is education can change. Challenging reason, hands-on and mind-on activities leads students to have contemporary skills and $21^{\text {st }}$ century experiences, experiential learning (Kolb and Kolb, 2005) states in the currently educational strategies because beliefs in no one learn without think and practice. The meaningful learning by head, heart, and hand with deep responsibility to social awareness is propagated at all level. The process of service learning seems to science teacher preparation in Thai university in terms of community service or preservice science teacher camp. However, student-centered based learning is implemented as it the project assignment.

Preservice science teachers decided to conduct project or science camp by norm or university culture. It cannot be indicated that real service learning implemented or occurred in the process of learning in higher education. They have learned culture and others community dimension by starting to select target community through group discussion via possibility of project cooperation. Then, they have to teach or construct school environments as well as school administrator wants. Finally, they move back to traditional class in university to register several courses by means of project ending and restart with another community that traditional ceremony recommended. It can be concluded that paradigm of community service is still implement in terms of traditional ceremony between community and preservice science teachers (Figure 1).

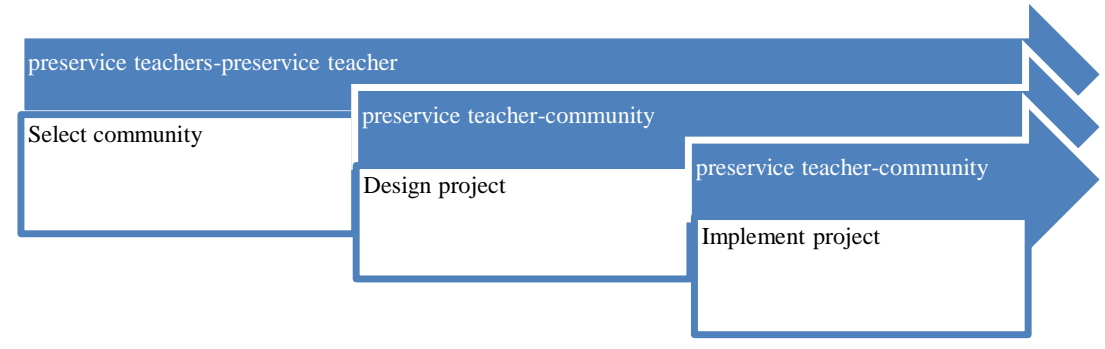

\section{Figure 1. Community Service And Preservice Science Teachers}

The instructional strategies of service learning can be generalized to preservice science teacher preparation with previous result of the study. Based on my teaching experiences and research findings (Prasertsang \& Nuangchalerm, 2013; Prasertsang et.al., 2013; Nuangchalerm, 2014a, Nuangchalerm, 2014b), it can be described that service learning can summarize at least 3 phases of instructional practices.

Preparation: it has been known that the initial phase of learning will hit the requirement of learning objectives preparation seems to classroom conditioning as it traditional for general classes. It is the first instructional process, allow students to have concept in teachers' role and community development. They spent time for planning of what project should be done and problem should be solved. They formed group and work with others by effective communication. Leadership is begun during project planning. Community pilot study is not ignored because it will give them necessary data to making decision. They gathered some information that concerns with community-based service learning by employing scientific thinking as well as science teachers be. This phase, stimulate and inspire their attributes of how to be a good citizen based on concept of good democracy, good citizen, and serving good community. They have to spent mostly time for preparation, not only project investigating community service but also knowledge in such they have to know before group entering.

Teacher will give them goal of working by lecture-based learning and group-based discussion with how to sustain community, especially implication of theoretical knowledge in classroom into real life situation.

Teacher as a key person to inspire students producing community service and stimulate them to have scientific thinking which is not emphasize theoretical perspectives but also case studies are introduced. Students take responsibilities to work with community members by various kind of knowledge construction such as observation, talking, photography, dialogues, community record, and so on to help them make possibility of successful in community service program. They are guided in teachers' profession and way of group working, team working, and problem-solving. Walk and talk are prior knowledge that they should do with community members. 
Action: everything will not be success if we deny learning by doing. The concept of any learning theory didn't ignore to stating students interact with natural world through direct experiences. Sensory organ works with brain function, it migrates perception by seeing, hearing, smelling, tasting, and touching. The second phase of service learning process let preservice teachers having experiences that looks different traditional classroom may be emphasized subject matters or theory-based learning. It allows them to work with community members and peers by conducting project as they planned, team-based learning, project-based learning, and problem-based learning. Learning activities help students to have $21^{\text {st }}$ century skills during action phase i.e. scientific thinking skills, life skills, innovation skills, ICT skills, science process skills, learning skills, and so on. They have to do as they plan with community members, project is implemented with assignment then various kind of data collection method are employed by video recording, photography, journal writing, discussion and report. Each group has to record and assess the goal of project by conducting a small research, interviewing, observing, making questionnaires, and videotape recording. The outcome of this process response the project in which serve community's needs with learning together between community and university. They have to talk with others, share ideas, construct knowledge through effective communication.

This phase teachers should divide preservice science teachers to group-based community service, each group consist of 10-15 person. Teacher is facilitator by guiding concept, methods, and techniques to do with community and also giving tools for collecting data and methodology for examining community service. Time for action is no too short or too long because it influenced to project-based service. Hidden curriculum, determined presrvice science teachers pay attention to community awareness, civic engagement, social responsibility that it difficult to understand in only theoretical-based classroom. Action is important methods open the world of knowledge to them. They have to move themselves to community and response to the real needs by doing with community members. Boundary of knowledge in social, cultural, political, and economical dimension is moved, they employed educational research after had learned from university. They can think and do various kinds of cooperating learning strategies.

Reflection: this learning process will be conducted when they back to classroom, presentation and reflection by whole class is set. Each group presents of what they did and how the project reaches the goal of study. The classroom activity assigned all group members prepare what they had learn through project-based construction and community service. Video recording, questionnaire, report, and presentation are important evidences to indicate successful in service learning.

“...I have a chance to repair school playground. When I do, it is not easier than those I think. Moreover, community members are warmest welcome to all students during project conducted..." Sunny

“...community members take care all of us with warmest welcome, food and supplies are transferred by community members to our service camp. The deepest expression that I remembered in the last day, he ride a bicycle followed our truck and shout loudly "forget me not, please revisit us"..." Lisa

“...the service project allowed us to fulfill knowledge and skills that we cannot buy anywhere, science show invite us to learning by happily doing because all of sectors such as students, community members, and school administrator give us to learn together in cooperatively..." Lita

“...service project taught us to plan, act, observe, and reflect in what we do. We learn to talk and discuss a lot for implementing community service. I am confidently project service employed active learning to us for knowledge construction..." Punch

Participants expressed their understanding in the concept of civic education and practical knowledge in terms of community service. They employed various kind of presentation i.e., powerpoint, poster, video, and report for concluding about what they had learned by project-based activity. Reflective writing is also employed to indicated that each of them reach the concept of citizenship. Moreover, ICT skills let them to make clip video to show of what and how they implement community-problem and community-project services through social network. Effective communication is such incubated and challenged them to learn how perceived a successful project. Also, it develops them to have science and art to share their ideas with others in which helps them to be good teacher and transporter of knowledge, skills, and expected attributes to all students. 


\section{DISCUSSION}

Teacher preparation program seems significant for shaping our society because teacher is an key person and factors that point society to of what we are. Program consists of both educational theories in which represent in classroom and also field experiences or school practicum. Educational policy promote way of effective teacher construction, as the current of teacher preparation in the world, teacher profession in the changing world must skeptic them to real life situation, solve the problem as they found, set a project, and service not only academic, but necessary skills might want to examine in the community. Field experiences in preservice science teachers declares knowledge and skills that include profession's attributes, community as a sources of learning, textbook cannot transmission of what students perceived even though they take time to work with community.

Based on individual differences, students have to adapt way of working, learn way of knowledge construction, and consume way of socio-cultural action. However, curriculum and instruction in university is limited to lecture-based learning or emphasizing theory than those practical learning. The concept if service learning is designed for $21^{\text {st }}$ century skills, suitable for creative learning innovation that students will learn from of what they work as well. The field experiences, sources of knowledge construction, difficult to teach in the classroom because it needs real and solve the problem by group working. It responses of what teachers should be success as good as teacher professions defined. ICT is employed and subject matter as they have learned, it will be used for creating learning innovation and community readiness.

The teacher preparation program is now time for updating or renovate curriculum by incorporating service learning strategies into science teacher preparation program, allowing them to meet profession and match the goal of program. The activities that found in the field experiences, service learning employed project-based and problem-based learning, suitable for higher education, and practical-based than those lecture-based classroom. Due to, instructional strategies examined student-centered learning, learning by doing emphasizes, problembased learning, and project-based learning which community is stakeholder.

Service learning can make professional teacher through project service, community and university is not far from borderline of academic or scholars, but it can make more closely by joining preservice science teachers with community members. Service learning can be summarized into 3 phases: Preparation, Action, and Reflection. Preservice science teachers and community members are planner to solve community problem (Zlotkowski, 2000). Higher-ordered thinking is key element that accelerate them to develop system thinking, academic outcomes, and skills according to Kolb (1984) states experiential learning that is process to develop abilities, experiences, and reflection (National Youth Leadership Council, 2010). Service learning initiated educators based on experiential learning (Kolb, 1984; Kolb \& Kolb, 2005) theory, methods, ideas, and concepts are emerged by inner and outer classroom activities (Zins et.al., 2010). It constructs positive relations among teacher, learners, and communities for enhancing learning skills and necessary abilities which they should be developed (Billig \& Conrad, 1997). They will have much more skills and abilities as $21^{\text {st }}$ century citizens. It should have by participation, problem-solving, planning, decision making, and practices. Community's problem had been solved, students learn to work with participatory action in collaboration with effective communication, life skills, and team working (Wiegand \& Strait, 2000; Ferrari III \& Cather, 2002). That is, it should be incorporated into classroom that higher education defined to hands-on and mind-on learning for citizens' learning in the $21^{\text {st }}$ century.

As believed in good teacher profession, preservice science teachers should fulfill learning experiences by outside activities and service communities as much as they can do. It can be considered that hidden curriculum in community service is not to help them in way of working together, but also learning the differences is required. Preservice science teachers apprentice teachers' role and responsibilities. In the way of service learning, they have to prepare community where showed clearly needs to work with. Preservice science teachers should think and act based on community needs and problem bases by service learning as shown in Figure 2 (Prasertsang \& Nuangchalerm, 2013). 


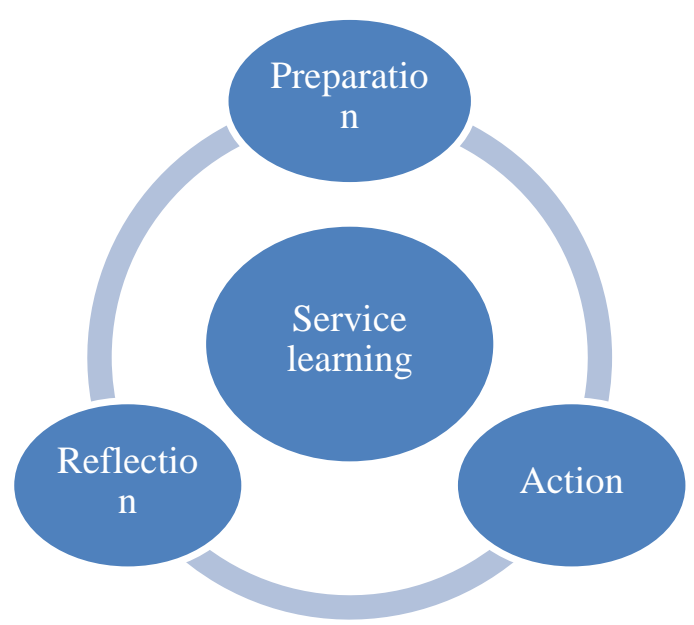

Figure 2. Service Learning Phases

They have a willing to serve community based on deep awareness to social responsibility, discuss of what they have learned from field experiences, and think about group-based learning through reflection (Clayton \& Ash, 2005; Deely, 2010). Learning innovation is created as well as they have learned from university and adapted to local practices (Power, 2010). It needs them to have skills helping them to survive, learn, adapt, and contemplative practices. The outcome of service learning enhance characteristic of good citizenship (Scott, 2006; Prasertsang et.al., 2013). It can be concluded that service learning explain itself in the role of education for holistic view in academic, skills, and attributes that response to social needs in the current situation and future. They have cooperating in participation in community sustainable development because they are outcomes of community to do and response to a partnership in education and development as well as they have a meaningful learning (Butin, 2005; Braskamp \& Engberg, 2011). Community care is a best way to let them participate in learning together with community members, happy, love, peace, awareness and social responsibility (Silcox, 1995; Galvan \& Parker, 2011).

Preservice science teachers can classify community needs, share ideas together, they have to develop many skills for serving community which is not only cognitive, but psychomotor and affective sides will be developed (Kaye, 2004). It seems to them research-based active classroom and more scientific thinking (Nuangchalerm, 2009; Cartwright, 2012; Cone, 2012). Service learning and community-based experiences are effective in developing teacher preparation program (Nuangchalerm, 2014a; Nuangchalerm, 2014). They can learn much more cultural, academic, and social awareness, which is now growing trend in higher education around the world. Preservice science teachers learn a powerful way about community in which cultures of learning embedded (Boyle-Baise \& Sleeter, 1998; Sleeter, 2000). It can be explained that direct experiences allow them to view, reflect, and change perspectives of how to develop their profession and attributes.

\section{ACKNOWLEDGEMENT}

I am very sincerely appreciated to Faculty of Education, Mahasarakham University for research supports.

\section{REFERENCES}

Astin, A.W. \& Antonio, A.L. (2012). Assessment foe excellence: the philosophy and practice of assessment and evaluation in higher education. $2^{\text {nd }}$ ed. Maryland: Rowman \& Littlefiled Publishers.

Bandura, A. (1993). Perceived self-efficacy in cognitive development and functioning. Educational Psychologist. 28(2): 117-148.

Bandura, A. (1997). Self-efficacy: the exercise of control. New York: Freeman.

Benneworth, P. \& Charles, D. (2013). University-Community Engagement in the Wider Policy Environment. In Benneworth, P. (Ed). University engagement with socially excluded communities. London: Springer Dordrecht Heidelberg.

Benneworth, P. \& Humphrey, L. (2013). Universities' perspectives on community engagement. In Benneworth, P. (Ed). University engagement with socially excluded communities. London: Springer Dordrecht Heidelberg. 
Billig, S.H. \& Conrad, J. (1997). An evaluation of the New Hampshire service-learning and educational reform project. Colorado: RMC Research.

Boyer, E.L. (1990). In search of community. Paper presented at the Annual Meeting of the American Council on Education. Washington, DC. January 18, 1990.

Boyle-Baise, M. \& Sleeter, C.E. (1998). Community service learning multicultural teacher education. Washington DC: ERIC document reproductive service No. ED 429925.

Braskamp. L.A. \& Engberg, M.E. (2011). How colleges can influence the development of a global perspective. Liberal Education. 97(3-4): 34-39.

Butin, D.W. (2005). Service-learning in higher education: critical issues and directions. New York: Palgrave Macmillan.

Butin, D. (2010). Service-learning in theory and practice: the future of community engagement in higher education. New York : Palgrave Macmillan.

Cartwright, T.J. (2012). Science talk: preservice teachers facilitating science learning in diverse afterschool environments. School Science and Mathematics. 112(6): 384-391.

Clayton, P. \& Ash, S. (2005). Reflection as a key component in faculty development. On the Horizon. 13(5): 161-169.

Clevenger, C.M. \& Ozbek, M.E. (2013). Teaching sustainability through service-learning in construction education. International Journal of Construction Education and Research. 9(1): 3-18.

Coffey, H. (2011). Moving into communities: developing cultural competence with pre-service teachers through community service-learning experiences. Partnerships: A Journal of Service-learning \& Civic Engagement. 2(2).

Cone, N. (2009a). A bridge to developing efficacious science teachers of all students: community-based Servicelearning supplemented with explicit discussions and activities about diversity. Journal of Science Teacher Education. 20: 265-383.

Cone, N. (2009b). Community-based service-learning as a source of personal self-efficacy: preparing preservice elementary teachers to teach science for diversity. School Science and Mathematics. 109(1): 20-30.

Cone, N. (2009c). Preservice elementary teachers' self-efficacy beliefs about equitable science teaching: foes Service learning makes a difference. Journal of Elementary Science Education. 21(2): 25-34.

Cone, N. (2012). The effects of community-based service learning on preservice teachers' beliefs about the characteristics of effective science teachers of diverse students. Journal of Science Teacher Education. 23(8): 889-907.

Daniels, K., Patterson, G. \& Dunston, Y. (2011). Meeting $21^{\text {st }}$ century teaching standards through servicelearning pedagogy in pre-service teacher education. Information for Action. 3(2).

Deely, S.J. (2010). Service-learning: thinking outside the box. Active Learning in Higher Education. 11(1): 4353.

Wigfield, A. \& Eccles, J.S. (2000). Expectancy-value theory of achievement motivation. Contemporary educational psychology. 25(1): 68-81.

Eyler, J. \& Giles, D.E. (1999). Where's the learning in service learning? California: Jossey-Bass Publishers.

Ferrari III, N.D. \& Cather, G.A. (2002). Community service, learning and the medical student. Education for Health. 15(2): 222-227.

Gallego, M. (2001). Is experience really the best teacher?: the potential of coupling classroom and communitybased field experiences. Journal of Teacher Education. 52(4): 312-325.

Galvan, C. \& Parker, M. (2011). Investigating the reciprocal nature of service-learning in physical education teacher education. Journal of Experiential Education. 34(1): 55-70.

Hart, A. \& Aumann, K. (2013). Challenging inequalities through community-university partnerships. In Benneworth, P. (Ed). University engagement with socially excluded communities. London: Springer Dordrecht Heidelberg.

Kaye, C. (2004). The complete guide to service learning. Michigan: Free Spirit Publishing.

Kolb, D.A. (1984). Experience as the source of learning and development. New Jersey: Prentice Hall.

Kolb, A.Y. \& Kolb, D.A. (2005). Learning styles and learning spaces: enhancing experiential learning in higher education. Academy of Management Learning \& Education. 4(2): 193-212.

National Youth Leadership Council. (2010). The service-learning cycle. Retrieved August, 2012, from http://www.nylc.org/sites/nylc.org/files/SLCycle_2PgHandOut.pdf.

Nuangchalerm, P. (2009). Preservice teachers perception about nature of science. The Social Sciences. 4(5): 463467.

Nuangchalerm, P. (2014a). Learning in science for $21^{\text {st }}$ century. Apichart Printing: Mahasarakham. (in Thai) 
Nuangchalerm, P. (2014b). Development of Service Learning for Preservice Science Teachers. Journal of Thonburi University. (in review).

Power, A. (2010). Community engagement as authentic learning with reflection. Issues in Educational Research. 20(1): 57-63.

Prasertsang, P. \& Nuangchalerm, P. (2013). The development of service learning instructional model for preservice teachers. Higher Education of Social Science. 4(3): 54-58.

Prasertsang, P., Nuangchalerm, P. \& Pumipuntu, C. (2013). Service learning and its influenced to pre-service teachers: social responsibility and self-efficacy study. International Education Studies. 6(7): 144-149.

Scott, V.G. (2006). Incorporating service learning into your special education program. Intervention in School and Clinic. 42(1): 25-29.

Silcox, H.C. (1995). Motivational elements in service-learning: meaningfulness, recognition, celebration, and reflection. Philadelphia: Brighton Press.

Sleeter, C.E. (2000). Strengthening multicultural education with community-based service learning. In O'Grady, C.R. (Ed). Integrating service learning and multicultural education in colleges and universities. New Jersey: Lawrence Erlbaum.

Wiegand, D. \& Strait, M. (2000). What is service learning?. Journal of Chemical Education. 77(12): 1538-1539.

Zins, J.E., Bloodworth, M.R. \& Wiessberg, R.P. (2007). The scientific base linking social and emotional learning to school success. Journal of Educational and Psychological Consultation. 17(2-3): 191-210.

Zlotkowski, E. (2000). Service-learning in the disciplines: strategic directions for service-learning research. Michigan Journal of Community Service-Learning. 7: 61-67. 